\title{
INDIE
}

Paweł Łysiak

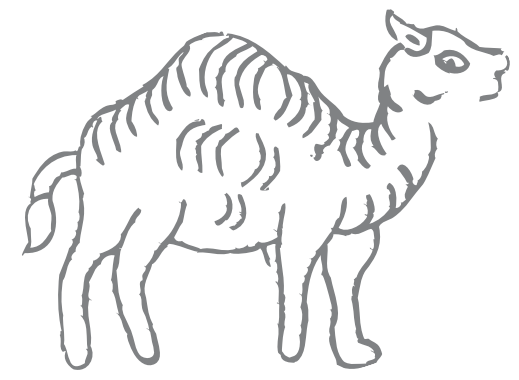

\section{INDIE JAKO WSCHODZĄCE MOCARSTWO EKONOMICZNE}

\section{Ekonomiczny czynnik mocarstwowości}

Niniejszy artykuł poświęcony jest ekonomicznemu czynnikowi mocarstwowości Indii. W świecie po zimnej wojnie to właśnie czynniki ekonomiczne w największym stopniu warunkują stosunki między państwami i coraz częściej postrzegane są jako najważniejsza zmienna potęgi państw. W określaniu charakteru i intensywności relacji między krajami coraz częściej przyjęto wskazywać czynniki kwantytatywne, które ze względu na swój charakter częściej odnoszą się do relacji gospodarczych, aniżeli do politycznych. Wskaźniki takie jak nominalny PKB, PKB per capita, PKB per capita wyrażony siłą nabywczą, coraz częściej wyznaczają potencjał państwa.

\section{Ekonomia potęgi globalnej}

Kołem zamachowym świata XXI w. będą więc stosunki gospodarcze i postęp naukowo-techniczny. Potęga państw narodowych mierzona będzie ich potencjałem gospodarczym. To z kolei oznacza, że wśród gospodarek wschodzących (emerging economies) stopa wzrostu gospodarczego oraz dana stopa wzrostu ludności ${ }^{1}$ pozwalać będzie na pomniejszanie lub poszerzanie luki rozwojowej wobec gospodarek rozwiniętych, w zależności od kierunku i siły korelacji.

\footnotetext{
${ }^{1}$ Arvind Virmani, A tripolar century: USA, China and India, New Delhi 2005, s. 8.
} 
Gospodarki rozwinięte, ze stosunkowo wysokim PKB per capita, zazwyczaj charakteryzują się powolnym wzrostem, a ewentualne rozbieżności w tempie rozwoju wynikają z różnic w zakresie poziomu wiedzy i technologii.

Gospodarki o niskośrednim dochodzie są bardziej zróżnicowane, a ich tempo rozwoju w znacznym stopniu zależy od rozmiarów strumieni transferu technologii z krajów wysoko rozwiniętych oraz jej adaptacji i zastosowania w rodzimej gospodarce. Transfery tego rodzaju dokonują się poprzez liczne kanały, takie jak: fizyczny import wyrobów zaawansowanych technologii, zagraniczne inwestycje bezpośrednie, internet, media i podróże np. stypendia i szkolenia zagraniczne, wspólne manewry².

Dzięki prowadzeniu odpowiedniej polityki w zakresie gospodarki narodowej, podatków, inwestycji w wymiarze zewnętrznym i wewnętrznym, „tygrysy azjatyckie” jako pierwsze osiagnęły pełne korzyści z globalizacji.

Za nimi podażzły kolejne azjatyckie gospodarki. W 1. 1980-2003, 8 z 10 najszybciej rozwijających się gospodarek świata pod względem średniego PKB per capita to gospodarki azjatyckie ${ }^{3}$.

\section{Wpływ demografii na rozwói gospodarczy}

Gwałtowny przyrost ludności Indii uznawany jest za jedną z głównych zmiennych w modelach rozwoju różnych instytucji. Przykładem tego może być model ICRIER (Indian Council for Research on International Economic Relations).

Rozpatrując istotę potencjału demograficznego, warto zwrócić uwagę na pewną ambiwalencję tej zmiennej. Wyraża się w tym myśl, że ogromny potencjał ludnościowy jest zarówno dobrodziejstwem, jak i obciążeniem. Pozwala bowiem wywierać znaczący wpływ na środowisko międzynarodowe, poprzez zwiększony potencjał wojskowy, wyrażony chociażby większymi możliwościami poboru, czy ekonomiczny wyrażany m.in. relatywnie dużym PKB w liczbach bezwzględnych. W efekcie może to czynić Indie bardzo atrakcyjnym rynkiem zbytu, rynkiem dla inwestycji bezpośrednich, ale jednocześnie krajem o ogromnym kapitale ludzkim, w którym poszukuje się specjalistów.

Bomba demograficzna, jak przyjęto to ujmować, miała katastrofalny wpływ na eksploatacje ograniczonych zasobów w gospodarce planowej typu swadeshi ${ }^{4}$.

Indie wkraczając w kolejną fazę rewolucji demograficznej, zdołały ograniczyć śmiertelność poprzez znaczną poprawę opieki medycznej oraz sprawne zapewnienie podstawowych potrzeb społecznych, podniesienie warunków sanitarnych itp., z dru-

2 Tamże.

3 Tamże. Tabela 3, w: Arvind Virmani, cyt. wyd.

${ }^{4}$ Termin powstał na określenie bojkotu zagranicznych towarów, szczególnie brytyjskich. Następnie wiązał się z tendencjami do osiagnięcia autarkii gospodarczej. 
giej strony jednak polityka narodzin nie była przez długie lata w ogóle formułowana, a w ostatnich latach nie dość skutecznie.

W latach 1900-1946, dochód narodowy Indii jako kolonii brytyjskiej rósł przeciętnie o $0,7 \%$ rocznie, roczna stopa wzrostu ludności zaś wynosiła $0,8 \%$ proc. Można zatem rzec, że gospodarka charakteryzowała się w długim horyzoncie czasowym stabilnym, lecz powolnym wzrostem. Dochód per capita w ujęciu realnym pozostawał natomiast niemal bez zmian.

Po odzyskaniu niepodległości, w okresie 1950-1991, wzrost gospodarczy gwałtownie przyśpieszył, osiagając średnioroczne tempo $3,9 \%$, w latach 80 . w wyniku II fali liberalizacji nawet 5,2\%, a w wyniku reform rozpoczętych w 1990 r., w latach VIII planu gospodarczego (1992-1997) średnio 6\% per annum.

Jednakże wzrost per capita był niewielki ze względu na wysoki przyrost naturalny ludności. Tak więc, mimo iż realny wzrost gospodarczy zanotowany po $1991 \mathrm{r}$. jest najwyższy od roku 1900, to po korekcie o przyrost naturalny jest on mniejszy niż wcześniejsze oczekiwania, a także mniejszy od wzrostu takich gospodarek jak Korea Południowa, Japonia, Tajwan czy Singapur, a już zdecydowanie mniejszy niż nominalny dwucyfrowy wzrost w Chinach, które ponadto prowadzą w porównaniu z Indiami bardziej restrykcyjną politykę demograficzną, której rezultatem w perspektywie czasu był wcześniejszy i szybszy spadek tempa przyrostu naturalnego.

\section{Lata 1991-2007. Otwarcie i modernizacja indyjskiej gospodarki}

Reformy początku lat 90 . spowodowane były przede wszystkim kryzysem płatniczym i koncentrowały się w pierwszej fazie głównie na sferze finansowej. Kryzys bilansu płatniczego przejawiał się deficytem handlowym sięgającym $3,2 \%$ PKB, deficyt budżetu centralnego i stanów indyjskich ogółem przekraczał 10\% PKB, średnio różnica między przychodami i wydatkami budżetowymi państwa wynosiła 3,5\% $\mathrm{PKB}^{5}$. Towarzyszyła temu wysoka i stale rosnąca inflacja, która w ujęciu rocznym wyniosła w sierpniu 1991 r. 16,7\%, a także negatywne zjawiska w zakresie zadłużenia publicznego. W okresie 1991-1992 osiagało ono poziom niemal 70\% PKB, a odsetki z tytułu długu publicznego stanowiły $70 \%$ deficytu centralnego budżetu. Centralnym punktem braku stabilności makroekonomicznej był rosnący od lat 70. deficyt sektora publicznego, a w rezultacie skokowy wzrost długu publicznego i odsetek z tego tytułu w latach 80 . Te negatywne tendencje w gospodarce były spotęgowane przez 2 wstrząsy. Po pierwsze - upadek Związku Radzieckiego, który wprowadził element dużej niepewności w zakresie eksportu, a ZSRR był przecież dotychczas jednym z najpewniejszych rynków zbytu dla indyjskich towarów. Po drugie - pierwszą wojnę w Zatoce, w rezultacie której wzrosły ceny ropy naftowej, i jaka wstrzymała transfery pieniężne

${ }^{5}$ Vijay L. Kelkar, South Asia in 2020: Economic outlook, [w:] Michael Chambers (red), South Asia in 2020: Future strategic balances and alliances, Strategic Studies Institute, Carlisle, Penn., 2002, s. 77. 
od indyjskich pracowników w państwach Zatoki ${ }^{6}$, a także zwiększyła presję na depozyty nie-rezydentów (NRI) w indyjskich bankach. Wysokie ceny ropy i zamrożenie wyżej wspomnianych transferów pogorszyły saldo obrotów bieżących Indii o 1,5 mld USD, a zewnętrzny bilans handlowy zwiększył się do 3,5\% PKB. Ponadto rezerwy walutowe Bank of India skurczyły się do poziomu 2,8 mld dolarów, pomimo udzielenia przez Międzynarodowy Fundusz Walutowy pomocy w wysokości 1,8 mld USD. W efekcie wskaźnik zasobów rezerw walutowych na pokrycie importu zmniejszył się do zaledwie 1,3 miesiąca, co zagroziło utratą płynności i postawiło Indie pod groźbą niewypłacalności. W kolejnych miesiącach rezerwa walutowa spadła do rekordowo niskiego poziomu poniżej $1 \mathrm{mld}$ USD, niewystarczającego do zaspokojenia importu przez okres 2 tygodni.

Władze Indii w odpowiedzi na kryzys finansów i rosnący deficyt bilansu płatniczego rozpoczęły wprowadzanie pakietu reform, mających na celu stabilizację sytuacji makroekonomicznej poprzez strukturalne przemiany gospodarki, wspomagane przez MFW. Pierwsza generacja reform rozpoczęła się w 1991 r. i ten rok zaczęto przyjmować jako przełom, nie tylko w odniesieniu do budżetu centralnego i finansów publicznych. Zdecydowano wtedy o zmianach o wiele dalej idących, realizowanych w latach późniejszych, związanych z reorientacją gospodarki: ze statycznej i w dużym stopniu nadzorowanej przez państwo na rynkowa, poprzez procesy liberalizujące. Powzięto pierwsze decyzje o ogólnych kierunkach rozwoju w przyszłości np. dotyczące otwarcia na inwestycje zagraniczne i zmiany w organizacji handlu zagranicznego. W rezultacie, gospodarka już w pierwszej fazie reform przyśpieszyła, przewyższając dotychczasowy poziom wzrostu, często nazywany w poprzednich dekadach mianem the Hindu Growth of 3,5\%. Przez najbliższe 10 lat po 1991 r. średnioroczny wzrost gospodarczy wynosił 6,4\%, a Indie znalazły się wśród 10 najszybciej rozwijających się gospodarek świata. W 1. 1992-97 poziom wzrostu wynosił rocznie $6,7 \%$, jednakże w następnych 5 latach tempo to spowolniło osiagając 5,8\%. Ogólnie mówiąc tempo wzrostu gospodarczego przyśpieszyło po 1991 r. w wyniku trwałego wzrostu wydajności i innowacji wszystkich czynników produkcji. Dodatkowym czynnikiem był znaczny postęp w kontroli przyrostu naturalnego, w wyniku czego wzrost dochodu per capita w okresie 1992-1997 wyniósł przeciętnie 4,4\% rocznie. Ponadto przyśpieszony wzrost gospodarczy wspomagany był przez niska, wynoszącą około 5\% stopę inflacji. W okresie 1970-1990 natomiast inflacja dwucyfrowa była zjawiskiem powszechnym.

Lata 90. to również otwarcie indyjskiej gospodarki na świat, któremu towarzyszył znaczny wzrost udziału indyjskiego handlu zagranicznego w handlu światowym. Obserwowano również skokowy wzrost udziału handlu zagranicznego w PKB Indii.

${ }^{6} \mathrm{~W}$ krajach rozwijających się transfery rodzimych pracowników pracujących za granicą nierzadko przewyższają wartość eksportu danego kraju oraz środki pomocy rozwojowej. MFW ocenia światową wartość tylko pieniężnych transferów na ponad 100 mld USD. Indie znajdują się na liście 10 państw o najwyższych transferach, wg MFW. Franz Nuscheler, Entwicklungspolitik, 2005, s. 302. 
Wskaźnik ten obecnie przekracza 30\%. Otwarcie gospodarki odbywało się również poprzez procesy liberalizacyjne. W ciagu 10 lat po roku 1991 zredukowano poziom ceł z 270 do przeciętnie $35 \%$, ograniczenia ilościowe na import natomiast zostały zniesione. Tendencje te miały zasadnicze znaczenie dla dalszego i trwałego wzrostu wydajności.

Kolejnym obszarem, w którym odniesiono sukces w badanym okresie, jest sektor finansowy, w tym bankowy oraz rynek ubezpieczeń. Ten segment rynku zaczął dynamicznie się rozwijać już w pierwszej fazie reform, a tempo rozwoju jeszcze przyśpieszyło po reformach, głównie eliminujących ukryte opłaty i prowizje pośredników finansowych. Zachęciło to inwestorów, zarówno zagranicznych (już teraz indyjskie papiery dłużne są popularne na rynkach zachodnich), jak również rodzimych.

Przyglądając się bliżej reformom pierwszej generacji, można stwierdzić, że dały one procesowi rozwoju gospodarczego całkowicie nowe podstawy. Świadczą o tym wskaźniki, ukazujące mniejszą zmienność stóp wzrostu oraz inflacji z roku na rok w stosunku do okresów poprzednich. Ponadto gospodarka obniżyła swojązależność od takich czynników, jak czas nadejścia i intensywność monsunu, ze względu na znaczny spadek udziału rolnictwa w wytworzonym PKB. Udział ten spadł do poziomu $25 \%$ w $2000 \mathrm{r}^{8}$. Wzrostowi udziału sektora usług towarzyszy natomiast proces specjalizacji usług, zwłaszcza w dziedzinie przemysłu zaawansowanych technologii IT, która zarazem napędza eksport, zatrudnienie i w konsekwencji cały produkt narodowy brutto. Wpływy z eksportu wyrobów zaawansowanych technologicznie wyniosły 12 mld USD, czyli jedną piątą wpływów z eksportu w 1999 r. W wyniku reform obniżyła się także wrażliwość gospodarki na szoki zewnętrzne, takie same, które wywołały konieczność tych reform. W latach 70. i 80. zwyżki cen ropy naftowej potrafiły zachwiać gospodarką w o wiele większym stopniu niż w latach 90., mimo że rozwój ekonomiczny przyczynił się do coraz większego zapotrzebowania na surowce energetyczne w ostatnich latach i teoretycznie ściślejszych związków między koniunkturą a cenami tychże. Między 1998 a 2001 r. zobowiązania z tytułu dostaw ropy wzrosły z 6,4 do 15,6 mld USD, z tego efekt cenowy był równy 2\% PKB, jednakże został efektywnie zrekompensowany wyższymi wpływami z eksportu. Niezwykle istotnym krokiem dla uodpornienia gospodarki na szoki podażowe było wprowadzanie polityki elastycznego kursu walutowego, co w połączeniu z ostrożnym podejściem do krótkoterminowego zadłużenia pozwoliło uchronić Indie od poważniejszych wstrząsów przy okazji kryzysu azjatyckiego w 1997 r., kryzysu w Brazylii rok później oraz kryzysu rosyjskiego w $1999 \mathrm{r}$.

W 1991 r. podjęto decyzję o deregulacji wielu gałęzi przemysłu oraz postanowiono zliberalizować rynek w celu przyciagnięcia inwestycji. Reformy makroekonomiczne i polityka otwarcia pociągnęły za sobą poprawę sytuacji gospodarczej i stworzyły nowe możliwości integracji Indii z gospodarką światowa, pomimo wie-

\footnotetext{
7 Vijay L. Kelkar, South Asia in 2020 ... cyt. wyd., s. 79.

${ }^{8}$ Dla porównania 55\% proc. w $1950 \mathrm{r}$.
} 
lu kwestii, które nie zostały rozwiązane. Pozostaje ponadto kwestia, czy przeprowadzone reformy wystarcza, by podtrzymać korzystne tempo przemian, które pozwoliłyby Indiom osiagnąć swój strategiczny cel i uzyskać status gospodarki globalnej. Co więcej od 1997 do 2001 r. wzrost gospodarczy spowolnił do mniej niż 6\% rocznie, a w 2002 r. przewidywano spadek tempa wzrostu do 5\%. Znacznie spadło tempo produkcji i inwestycji krajowych brutto, między innymi w wyniku załamania na rynku kapitałowym, które trwało od połowy lat $90 .{ }^{9}$ Najbardziej dotkliwie odczuwane było spowolnienie eksportu, ponieważ oznaczać mogło zmniejszenie źródeł finansowania zobowiązań oraz ograniczenie możliwości realizacji strategicznych celów rządu, m.in. walki z ubóstwem, korupcją czy analfabetyzmem. Tempo wzrostu eksportu spadło z $22,6 \% \mathrm{w} 2000 \mathrm{r}$. do zaledwie $1,9 \% \mathrm{w}$ roku następnym. Tak drastyczny spadek mógł oznaczać pogorszenie koniunktury, co jest zjawiskiem typowym w gospodarkach rynkowych, jednak w obliczu debaty wokół oceny przeprowadzonych reform odczytywany był przez zwolenników dalszych reform jako niepokojący sygnał. Również finanse publiczne Indii znacznie się pogorszyły. Świadczy o tym przekraczający 10\% PKB deficyt budżetu centralnego i budżetów stanowych, jaki osiagnął niemal poziom z $1991 \mathrm{r}$.

Na przełomie wieków rząd zlekceważył zbyt szybko rosnący w stosunku do spowolnionego tempa wzrostu gospodarczego deficyt, nie tylko realną możliwość obniżenia wzrostu do psychologicznego poziomu the Hindu Growth of 3,5\%. Nie wzięto również pod uwagę pułapki zadłużeniowej. Według scenariuszy ekonomistów MFW, przy braku reformy finansów publicznych deficyt w 2020 r. może zająć czwartą część, a skumulowany dług aż $140 \%$ produktu krajowego brutto ${ }^{10}$. Na szczęście w lutym 2001 r. w łonie rządu rozpoczęto debatę nad obszernym pakietem reform. Przedstawiony przez Radę ds. Ekonomicznych przy urzędzie premiera katalog reform został wsparty przez projekty X Planu Pięcioletniego na lata 2002-2007, przedstawionego przez Komisję Planowania. Rosnąca świadomość na szczeblu politycznym zaś zaowocowała wsparciem reform przez Narodową Radę Rozwoju (NDC), skupiającą liderów indyjskich partii politycznych, przede wszystkim w zakresie działań na rzecz ograniczenia ubóstwa o $20 \%$ do 2007 r. oraz podwojenia produktu krajowego brutto per capita w ciagu 10 lat. Środkami do osiągnięcia tych celów miały być reformy zwiększające otwartość, produktywność oraz programy do walki z ubóstwem. Celem strategicznym było osiągnięcie wzrostu PKB na poziomie 8-10\% per annum.

Dwucyfrowy wzrost i efektywna walka z ubóstwem wymagają zwiększonych nakładów inwestycyjnych, idących w parze z poprawą wydajności czynników produk-

${ }_{9}$ Roczne tempo wzrostu produkcji spadło z 12\% w 1995 do 2,1\% w 2001, krajowy poziom inwestycji w stosunku do PKB spadł z 26,8\% w 1995 do 23\% w 1999, ilość nowych emisji akcji i walorów dłużnych jednostek niepaństwowych spadła z 1678 w 1995 do 79 w 1999 r. Dane pochodzą z: Vijay L. Kelkar, South Asia in 2020..., cyt. wyd., s. 81.

${ }_{10}$ Tim Callen (red.), India at the crossroads: Sustaining growth and reducing poverty, Washington DC: International Monetary Fund, 2001. 
cji. Zakres reform musi zostać poszerzony. Tzw. reformy II generacji oparte są na bardziej kompleksowych działaniach w różnych dziedzinach życia. W aspekcie ekonomicznym wyróżnia się poziom mikro-, mezo- i makroekonomiczny. Podział ten odzwierciedla strategiczne cele ekonomiczne Indii.

Reformy makroekonomiczne to przede wszystkim dalsza naprawa finansów publicznych. W procesie transformacji gospodarczej najważniejsze jest, by finanse publiczne nadążały za tempem zmian w pozostałych sektorach. Dlatego nie wystarczyło poprzestać na reformach parlamentu 1991 r., lecz zaplanować kolejną serię zmian. Debata w parlamencie na ten temat zaczęła się wiosną 2002 r. Projekt ustawy o finansach publicznych (Fiscal Responsibility Bill) ${ }^{11}$ z 2002 r. przewidywał stworzenie nowych, a zarazem docelowych ram prawnych i instytucjonalnych w zakresie finansów publicznych w dłuższym horyzoncie czasowym. Przez 5 lat deficyt budżetowy nie mógł przekroczyć $2 \%$ PKB, co hamowało wzrost długu publicznego, dla którego i tak ustawa przewidywała dodatkowo limit w stosunku do PKB, również w horyzoncie pięciu lat. Ustawa kładła nacisk na przejrzystość procedur budżetowych, również w fazie przygotowania, jako na istotny element utrzymania dyscypliny fiskalnej. Dziesięcioprocentowy deficyt budżetowy w ponad 1/3 swej wartości był rezultatem fatalnego stanu finansów stanowych. Dlatego inicjatywy odnośnie korekty fiskalnej na szczeblu centralnym powinny być teraz przykładem dla stanów. Konsekwencją korekt budżetowych powinna być z kolei obniżka długookresowych rynkowych stóp procentowych z obecnych $6-7,75 \%{ }^{12}$ do $3-4 \%$. Obniżenie kosztów kapitału w oczywisty sposób zwiększyłoby jeszcze bardziej inwestycje i innowacyjność, ale także poprzez mechanizm kursu walutowego wsparłoby liberalizację handlu. W ramach uzdrawiania finansów publicznych w Indiach konieczne wydaje się również ograniczenie wydatków i zwiększenie przychodów sektora. Można tego dokonać choćby redukując ogromne subsydia dla państwowych przedsiębiorstw, które tylko w $1998 \mathrm{r}$. wyniosły 63 mld USD ${ }^{13}$. Wycofując się z tej polityki, dzięki zmniejszeniu zjawiska „wypychania”, można by zapewnić lepszą alokację kapitału w sektorze prywatnym, a poprzez rozwój tego sektora, zwiększone wpływy budżetowe z tytułu podatków. Tego typu rozumowanie wydaje się być słuszne w przypadku Indii, gdyż skądinąd wiadomo, że Indie potrzebują rozwoju sektora prywatnego, w tym celu m.in. przyciaggają inwestorów zagranicznych. Stopa zwrotu po opodatkowaniu przedsiębiorstw państwowych, po uwzględnieniu dotacji, wynosi średnio niecałe 3\%. Uwzględniając specyfikę indyjskiej ekonomii politycznej, proces prywatyzacji powinien przebiegać inaczej, niż miało to miejsce w Europie Środkowej i Wschodniej, a także inaczej niż w Ameryce Łacińskiej. Ze względu na dużą wartość sektora publicznego, a także wielkość gospodarki, prywatyzacja powinna mieć przede wszystkim jawny i przejrzysty przebieg. Przy specyfice indyjskich stosunków wewnętrznych, a także sytu-

${ }^{11}$ Vijay L. Kelkar, South Asia in 2020 ..., cyt. wyd., s. 84.

${ }_{12}$ Strona Reserve Bank of India, URL < http://www.rbi.org.in/home.aspx>, 12.05.2007.

13 Vijay L. Kelkar South Asia in 2020..., cyt. wyd,, s. 85. 
acji geopolitycznej, należy także wyłączyć z prywatyzacji takie gałęzie, jak energia atomowa, przemysł kosmiczny i zbrojeniowy. Dochody budżetowe należałoby także zwiększyć poprzez większą ściaggalność podatków, np. dzięki zastosowaniu nowoczesnych technologii w tej dziedzinie. W 2002 r. rozważano również likwidację większości zwolnień i ulg podatkowych. Wszystko po to, by zwiększyć o 4-5\%. wskaźnik wpływów podatkowych w stosunku do PKB, który w Indiach wyniósł w 2002 tylko $14 \%$, podczas gdy uważane za „bardziej liberalne” kraje jak Korea czy Malezja zanotowały odpowiednio $17 \%$ i $19 \%$.

Reformy mezoekonomiczne to reformy w sektorach, mające na celu przede wszystkim poprawę ich wydajności. Sektory znajdujące się w ramach sektora publicznego, takie jak energetyczny, transport i komunikacja, charakteryzują się średnio rozwiniętą infrastruktura, która zmniejsza konkurencyjność całej gospodarki. Celem reform na tym poziomie jest przede wszystkim podjęcie decyzji, które sektory należy prywatyzować, a które pozostawić w sektorze publicznym, ale zrestrukturyzować i zmodernizować. Modernizacja dotyczyłaby także sposobów zarządzania. W tym celu Indie muszą przyciagać inwestorów zagranicznych. Ocenia się, że skumulowane zapotrzebowanie na inwestycje infrastrukturalne do $2022 \mathrm{r}$. wyniosą od 1,6 do 3,6 bln USD ${ }^{14}$. Efekty przełożenia tych inwestycji na gospodarkę mogą wynieść do 4\% PKB rocznie, co miało miejsce w Chinach. Reformy mezoekonomiczne obejmują także dalszy rozwój bazy instytucjonalnej, warunkującej z kolei rozwój społeczeństwa obywatelskiego. Jest to o tyle ważne, że w przypadku Indii często podkreśla się kapitał ludzki tego kraju, chociażby przy okazji szkolnictwa wyższego, ośrodków badawczych dla przemysłu IT lub diaspory w krajach Zatoki i w USA. Reformy z tego poziomu próbują tworzyć powiązania typu: szkoły wyższe-ośrodki badawcze-przemysł, poprzez różne programy rządowe.

Reformy mikroekonomiczne ukierunkowane są na rozwój konkurencji na rynkach towarów, środków produkcji i na rynku usług, poprzez likwidację barier wejścia, a także poprawę warunków wolnej konkurencji w handlu międzynarodowym i w odniesieniu do inwestycji zagranicznych. W $2002 \mathrm{r}$. Indie, z ich podstawową stawką celną wynoszącą $34 \%$, zaliczały się do gospodarek o jednej z najbardziej protekcjonistycznych polityk handlowych w regionie i na świecie. Celem reformy w tym zakresie jest obniżenie stawek celnych do standardów krajów Azji Południowo-Wschodniej i Chin do 2010 r. oraz do standardów członków OECD do 2020 r. Dodatkowym założeniem reformy celnej jest powodzenie porozumień regionalnych w kwestii utworzenia południowoazjatyckiej strefy wolnego handlu (SAFTA). Ocenia się, że jeśli udałoby się zmniejszyć ograniczenia ilościowe o połowę, zyski z tego tytułu wyniosłyby 1,5 proc. projektowanego PKB, a jeżeli dodać do tego wpływ redukcji ceł, efekt zysku byłby jeszcze większy, dzięki bardziej efektywnej alokacji kapitału, nawet przy teoretycznym założeniu braku zwiększania realnego majątku.

14 Tamże, s. 87. 
Reformy II generacji poruszały również kwestię małych i średnich przedsiębiorstw (MSP), które ze względu na swoją elastyczność mają ogromny potencjał w zakresie zwiększania zatrudnienia oraz wyrównywania nierównomiernego rozwoju pomiędzy regionami. Stworzenie dogodnych warunków dla rozwoju sektora MSP pozwala na przesunięcie na poziom lokalny części zadań rządowej strategii walki z ubóstwem. Dotychczas rząd utrzymywał liczne nieracjonalne ograniczenia zarówno nakładów inwestycyjnych w sektorze MSP, jak i w ogóle rozpoczęcia przez prywatnych przedsiębiorców niektórych rodzajów działalności. Należało zweryfikować zasadność tego typu ograniczeń, jako że zmniejszały one wolumen eksportu produktów wielu gałęzi, a także ograniczały wytwórczość, co przy stałym wzroście popytu wewnętrznego prowadziło do zwiększenia importu. Kwestia znoszenia tych ograniczeń była kwestią wrażliwą w Indiach, budziła opór przedstawicieli tradycyjnej wytwórczości. Przyjęto jednak sugestie tzw. Komitetu Abida Hussaina ${ }^{15}$, by znosić je stopniowo, zaczynając od tych, które w największym stopniu ograniczają potencjalny eksport.

FDI w ujęciu netto rosły z 74 mln w 1991 r. do 3,6 mld w roku 1997, w którym zanotowano największy poziom FDI. Wzrost ten był zatem ogromny, jednakże odnosząc jego wielkość do Chin, które przyciagnęły w 1997 r. inwestycje warte 44 mld USD, można go uznać za wciąż niewystarczający. W okresie 1997-2002 sytuacja nie zmieniła się. Chiny skupiały ponad $10 \%$ wszystkich światowych zagranicznych inwestycji bezpośrednich (FDI), Indie zaś niecały 1\%. Indie powinny naśladować Chiny w umiejętności korzystania z globalizacji gospodarki, FDI bowiem zapewniają napływ nowych technologii, know-how i pośrednio zwiększają wydajność. Indie dotychczas w porównaniu z Chinami są mniej zaawansowane w tworzeniu przyjaznych warunków dla FDI. Jest to kwestia rozbudowy infrastruktury, która sama w sobie napędza gospodarkę, stworzenia przejrzystego i spójnego systemu prawnego, ograniczenie barier wejścia/wyjścia dla przedsiębiorstw, a także podjęcia walki $\mathrm{z}$ biurokracją i korupcja.

Jednakże w Indiach decyzje dotyczące reform opóźniane są przez brak stabilności politycznej. Złożone z wielu partii, niestabilne koalicje oraz ciąłość rządów, podtrzymywana przez polityczne targi i doraźne obietnice, nie stwarza klimatu dla uchwalenia reform. W czasie rządów, prowadzonej przez Bharatiya Janata Party (BJP), koalicji NDA (National Democratic Alliance) wprowadzenie nowych reform hamowane było przez przejmowanie środków budżetowych na wybory. Od końca 2002 r., jak również przy planowaniu i wykonywaniu budżetu na 2003 r., rząd rozpoczął kampanię wyborczą przed wyborami zaplanowanymi dopiero na przełom kwietnia i maja w 2004 r.. W połowie 2002 r. premier Atal Bihari Vajpayee, cytując ekspertyzę Second National Commission on Labour, podkreślił konieczność przeprowadze-

${ }_{15}$ The Abid Hussain Committee to Komitet Ekspertów ds. Małych Przedsiębiorstw przy rządzie Indii (Expert Committee on Small Enterprises), którego celem jest opracowanie strategii dla sektora MSP. Wyniki ekspertyz Komitetu potwierdzają, że likwidacja barier wejścia do sektora i większa konkurencja ma pozytywny wpływ na wyniki sektora MSP. 
nia reform oraz mówił o osiagniętym kompromisie w tym zakresie. W 2003 r., rok przed wyborami, podczas Indyjskiego Szczytu Gospodarczego, minister handlu Indii Arun Jaitley ponownie podkreślił konieczność reform, ale sprzeciwił się zbyt pośpiesznym zmianom.

Po wyborach w maju 2004 nadzieje na to, że koalicja UPA (United Progressive Alliance) będzie kontynuować reformy pod przywództwem Partii Kongresowej, tylko nieco się ożywiły. Według Roba Jenkinsa, współautora pracy o charakterze indyjskich reform gospodarczych, sprzeciwu wobec nowej generacji reform odnośnie prawa pracy nie demonstrują wyłącznie związki zawodowe i inne organizacje pracownicze. Wiele mówi się o mobilizacji Indusów w związku z powszechną świadomością, że obecna szansa na rozwój może się nie powtórzyć. Jednak cytowane przez Jenkinsa opinie świadczą o tym, że nawet wśród wysokich urzędników służby cywilnej przeważa opinia, że w obecnej sytuacji politycznej, przy rozdrobnionych koalicjach, nie ma nadziei na kontynuację reform ${ }^{16}$. $\mathrm{Z}$ drugiej strony, Kongres charakteryzuje się pragmatycznym podejściem, zważywszy choćby na koalicję z partią komunistyczną. Ponadto polityka koalicji UPA potwierdza prognozy scenariuszy odnośnie do reform II generacji. Najbardziej prawdopodobny scenariusz zakłada, że reformy będą kontynuowane, wprawdzie nieco wolniej, ale za to bazując na zakumulowanej korzyści już przeprowadzonych reform. To powoduje, że reformy gospodarcze będą prowadzone w wolniejszym tempie, ale zdaniem wielu pozwolą wyeliminować ryzyko niepokojów społecznych. Polityczne niestabilności nie zniechęcają inwestorów w dłuższym okresie. Po zamachach w Bombaju 12 lipca 2006 r. rupia spadła gwałtownie, ale jeszcze tego samego dnia zaczęła drożeć.

\section{Gospodarka Indii w 2006 roku}

Najnowsze statystyki gospodarcze dotyczące indyjskiej gospodarki są nieco mniej optymistyczne niż to zakładano w połowie lat 90 . XX w. Wciąż bowiem statystyki porównują Indie $\mathrm{z}$ dynamicznie rozwijającymi się Chinami i nie pozwalają Indiom zapomnieć o tzw. kompleksie chińskim, którego ekonomiczny wymiar odzwierciedlony jest głównie w liczbach, szczególnie statystyce wzrostu nominalnego PKB.

Jaram Ramesh, ekonomista i członek parlamentu Indii, stworzył pojęcie „Chindia”, opisane szerzej w jego książce Making Sense of Chindia. W swojej pracy próbuje on zweryfikować kilka hipotez, m.in. o podobnym charakterze wzrostu Chin i Indii, a w związku z tym o możliwości porównywania obu gospodarek, oraz tezę

${ }^{16}$ Rob Jenkins and Sunil Khilnani (red.), The politics of India's next generation of economic reforms, Special Issue of "India Review" (Washington, DC), Vol. 3, No. 2 (Listopad 2004). 
głoszącą wzajemne poszanowanie i współpracę obu państw w równoległym dążeniu do mocarstwowości ${ }^{17}$.

Najnowsze szerokie studium autorstwa Barry'ego Boswortha i Susan Collins, p.t. Rachunek wzrostu. Porównanie Chin $i$ Indii ${ }^{18}$, zestawia wyniki obu gospodarek za okres 1978-2004, przy czym szczególny akcent położony jest na okres 1993-2004, a zatem następujący bezpośrednio po strukturalnych reformach liberalizujących indyjską gospodarkę.

Biorąc pod uwagę ostatni wymieniony okres, wzrost gospodarczy Indii wyniósł $6,5 \%{ }^{19}$, podczas gdy chiński $9,7 \%$ rocznie. Należy również analizę tę pogłębić o dane demograficzne. Biorąc pod uwagę wyższy przyrost naturalny w Indiach, wzrost realnego dochodu per capita był tu 2 razy mniejszy.

W obu krajach wzrost był w niewielkim tylko stopniu tworzony przez wzrost w sektorze zatrudnienia - dla Indii wskaźnik ten wyniósł 1,9, dla Chin zaś 1,2 punktu procentowego.

O rozbieżnym charakterze wzrostu obu krajów świadczy dynamiczny wzrost produkcji. Miernik wzrostu produkcji w przeliczeniu na 1 zatrudnionego w Indiach (inaczej niż w Chinach) rośnie wolniej niż PKB osiagając 4,6\% per annum (w Chinach $8,5)$. Rozkład tego wzrostu wynika w połowie z dodatniej zmiany aktywów rzeczowych, przypadających na pojedynczego zatrudnionego, a druga połowa wynika ze wzrostu wydajności czynników produkcji, co jest pozytywnym zwiastunem dla dalszego wzrostu w kolejnych okresach.

Znamienne może okazać się porównanie do innych dynamicznie rozwijających się gospodarek Azji Południowo-Wschodniej: Tajlandii, Malezji, Indonezji, Singapuru, Filipin, a także Korei Południowej w Azji Północno-Wschodniej oraz Tajwanu. Indie w ostatnich latach często określane są mianem ,potencjalnego kolejnego azjatyckiego tygrysa", tym razem w Azji Południowej. Warto zwrócić jednak uwagę, że w okresie przyśpieszenia wzrostu gospodarczego w Indiach, z poziomu tzw. The Hindu Growth of 3,5\% do poziomu obecnego, ponad 7\% per annum przypisuje się temu zjawisku wielką wagę. Natomiast we wszystkich wyżej wspomnianych krajach, ,azjatyckich tygrysach”, w dowolnych dłuższych okresach między 1960 a 1980 r. produkcja, czyli podstawowy czynnik wzrostu PKB, rosła średnio w podobnym tempie lub tylko nieco wolniej niż w Indiach, ale tylko w najnowszym, najbardziej dynamicznym okresie 1993-2004.

Istotna różnica widoczna jest pod względem produktywności jako czynnika wzrostu. W tym samym okresie w Indiach wzrost produktywności czynników produk-

${ }_{17}$ Peter Ghooi, recenzja książki Jairama Ramesha, Making sense of Chindia, URL http://www. chillibreeze.com/bookreviews/MakingSenseofChindia.asp, 16.09.2007.

18 Accounting for growth: Comparing China and India, Working Paper 12943, February 2007, National Bureau of Economic Research, URL <http://www.nber.org>.

${ }_{19}$ Wszystkie dane w tym rozdziale (o ile nie wskazano innych źródeł) pochodzą ze studium Accounting for growth: Comparing China and India, cyt. wyd., chyba, że opisane inaczej. 
cji wyniósł 2,3 punktu procentowego samego wzrostu per annum. A dla całej wyżej wspomnianej grupy krajów Azji Południowo-Wschodniej, Korei Południowej i Tajwanu wskaźnik ten wyniósł zaledwie 1,2 punktu procentowego per annum w latach 1960-1980. W kolejnych latach liczba ta jeszcze malała osiagając 1,4 punktu w okresie 1980-1993 oraz jedyne 0,3 punktu w najnowszym okresie 1993-2003, a więc statystycznie analogicznym dla okresu ujęcia tego wskaźnika dla Indii.

Jeżeli chodzi o wyniki w poszczególnych sektorach gospodarki, to należy podkreślić, że postępowi towarzyszy przesunięcie punktu ciężkości do kolejnych sektorów, zwłaszcza zaś do III sektora (do usług).

Odnośnie do sektora rolnictwa, to rozwijał się on w Indiach w tempie 2,2\% rocznie w analizowanym okresie, czyli mniej niż inne gospodarki w regionie - np. Chiny zanotowały wzrost $3,7 \%$. Ponadto w Indiach wzrost był w mniejszym stopniu efektem zwiększonej produktywności, w większym zaś procentowego przyrostu zatrudnienia w sektorze, co nie jest dobrym zwiastunem dla gospodarki, gdyż może obniżać jej konkurencyjność w dłuższym okresie. Przyrost zatrudnienia w rolnictwie nie jest wynikiem gry o sumie zerowej, nie powoduje bowiem odpływu zasobów ludzkich z innych, często dynamicznie rozwijających się branż. Jest najczęściej efektem względnie wyższego przyrostu naturalnego na obszarach wiejskich.

W badanym okresie indyjski sektor przemysłowy rósł średniorocznie o 7,7\%, przy czym udział w tym wzroście wzrostu efektywności to 1,1 punktu procentowego na rok. Udział przyrostu zatrudnienia natomiast to ponad trzykrotnie więcej (aż 3,6 punktu procentowego). Statystyki te nie wyróżniają się in plus wśród innych gospodarek regionu. Dynamika wzrostu wydaje się być znacząca, jedynie gdy weźmie się pod uwagę nominalny potencjał gospodarczy. Ale i pod tym względem Indie ustępują Chinom, które są zarówno większą gospodarką jak i bardziej dynamiczną w większości analizowanych przypadków. Wzrost sektora przemysłowego wynosi tam np. średniorocznie $11 \%{ }^{20}$.

Sektorem rynku, na którym Indie zgodnie z wcześniejszymi prognozami osiągnęły w badanym okresie znaczny sukces, są usługi, uważane częstokroć za najbardziej przyszłościowy sektor gospodarczy. Należy być jednak ostrożnym w ocenie, ponieważ duży udział tzw. III sektora w uzyskiwanym dochodzie narodowym odnotuje się w państwach najwyżej rozwiniętych, a często w krajach rozwijających się lub nawet w krajach najsłabiej rozwiniętych (least developed countries, LDC). Sektor usług jest bowiem niezwykle niejednorodny, obejmując usługi wysoko wyspecjalizowane, gwarantujące wysokie marże, jak i niezwykle proste rodzaje usług. Kryterium klasyfikacji do III sektora jest zazwyczaj charakter produkcji, a nie uzyskiwany dochód lub marża.

${ }^{20} \mathrm{~W}$ przeliczeniu na 1 zatrudnionego chińska produkcja rosła o 9.8 proc. p.a., z czego co najmniej 6,2 punktów proc. przypadało na wzrost wydajności. Źródło: Chiny i Indie nadal będq się szybko rozwijać, „Gazeta Prawna”, „Financial Times”, 30 marca 2007. 
W analizowanym okresie wartościowo usługi w Indiach rosły średniorocznie o 9,1\%, w tym udział efektywności czynników produkcji wynosił 3,9 punktu procentowego, znacznie więcej niż w Chinach, gdzie ogólny wzrost podyktowany był w pierwszej kolejności wzrostem zatrudnienia w usługach ${ }^{21}$.

Indie stały się w latach 90. jednym z kluczowych graczy w świecie w zakresie handlu usługami. Tylko przez lata 90. udział Indii w tej dziedzinie wzrósł dwukrotnie z 0,6 do $1,2 \%$, co jest niesłychanym sukcesem New Delhi oraz analogią dla wzrostu Chin w wytwórczości i eksporcie produktów ${ }^{22}$.

Ogólnie w 2007 wzrost PKB w Indiach może przekroczyć nawet 10\%, a według prognoz OECD może być on obok wzrostu PKB Chin główną siłą napędową globalnej gospodarki w $2007 \mathrm{r}^{23}$ Natomiast pod względem konkurencyjności gospodarki, według ocen Światowego Forum Ekonomicznego w Davos, Indie podwyższyły swoją pozycję o dwa miejsca, a uzyskując 4,41 punktu zajęły 43 pozycję i znalazły się w grupie krajów Top 50, wyprzedzając Chiny (54 pozycja) oraz kilka krajów Unii Europejskiej, w tym Polskę i Grecję ${ }^{24}$.

Studium The Accounting for Growth twierdzi, że od strony podażowej perspektywy dalszego szybkiego wzrostu Indii sq bardzo pomyślne ${ }^{25}$, ponieważ inwestycje w rzeczowe aktywa trwałe osiagają już poziom niemal 30\% PKB. Warunkiem dla dalszego wzrostu stopy inwestycji w Indiach jest dalsza poprawa ich bilansu płatniczego, ale co równie ważne, większy niż obecnie strumień długoterminowego kapitału zza granicy. Strumienie kapitału krótkoterminowego są coraz większe. Inwestorzy w gospodarkach wysokorozwiniętych są coraz bardziej zainteresowani w lokowanie środków na azjatyckich rynkach, najczęściej poprzez fundusze.

Poziom życia Indusów to zaledwie 1/10 średniego poziomu państw wysokorozwiniętych ${ }^{26}$. Szanse na rozwój są zatem ogromne. Dotychczas wzrost Indii opierał się na relatywnie taniej, lecz wysoko wykwalifikowanej i wykształconej sile roboczej. Zachodnie firmy przenosiły do Indii obsługę rachunkową lub biura obsługi klientów. Obecnie można już mówić o przenoszeniu całej produkcji lub usług. Powstało kilka ośrodków przemysłu zaawansowanej technologii, które przeradzają się w luksusowe centra przyszłych miast. Przy czym rząd jest świadomy konieczności walki z ubóstwem, jako warunku koniecznego osiagnięcia trwałego wzrostu. Według danych z 2006 r. w Indiach 300 mln ludzi żyło w nędzy ${ }^{27}$.

Wśród państw rozwijających się Indie wykazują jedno z najwyższych temp rozwoju, zarówno pod względem ilościowym, mierzonym wzrostem nominalnego i re-

${ }^{21}$ Tamże.

${ }^{22}$ Vijay L. Kelkar, South Asia in 2020 ..., cyt. wyd., s. 96.

${ }^{23}$ Dobre wieści na nowy rok 2007: czas azjatyckich tygrysów, „Rzeczpospolita”, 2.01.2007.

${ }^{24}$ Global competitiveness report 2006-2007, World Economic Forum Webpage, URL < http://www. weforum.org/en/initiatives/gcp/Globalproc.20Competitivenessproc.20Report/index.htm>.

${ }^{25}$ Chiny $i$ Indie nadal będa się szybko rozwijać, cyt. wyd.

26 Tamże.

${ }^{27}$ Danuta Walewska, Hinduski tygrys rośnie w siłe, ,Rzeczpospolita”, 14.08.2006 r. 
alnego produktu krajowego brutto, jak i jakościowo wyrażanym wzrostem kapitału ludzkiego i związanych z tym odpowiednich mierników. $Z$ tego względu, ale także z powodu rozmiaru terytorialnego, potencjału ludnościowego i położenia geostrategicznego Indie stały się jednym z kilku modeli rozwojowych dla innych państw rozwijających się w Azji i Afryce, o podobnym wyjściowym poziomie rozwoju gospodarczego. Po odzyskaniu niepodległości Indie stały się poligonem dla różnych idei wzrostu i rozwoju. Jednakże w $1991 \mathrm{r}$. Indie niejako zmuszone zostały porzucić wypracowany przez siebie rodzimy model centralnego sterowania z elementami planowania i demokratycznej regulacji na rzecz polityki liberalizacyjnej, prywatyzacji i otwarcia swej zamkniętej dotychczas gospodarki.

Pod względem ilościowym, takie wskaźniki jak urbanizacja, industrializacja, sekularyzacja, edukacja oraz dobrobyt, plasują Indie jako typowy kraj najsłabiej rozwinięty (LDC), charakteryzujący się nielicznymi jedynie atrybutami demokracji w sensie rzeczywistym, czyli społeczno-ekonomicznym (nie zaś formalno-instytucjonalnym).

$\mathrm{Z}$ drugiej jednak strony, w aspekcie jakościowym Indie osiagnęły relatywnie najwyższy wśród krajów rozwijających się poziom rozwoju instytucjonalnego, który w swoisty sposób umacnia demokratyczną bazę instytucji społecznych i politycznych (polity), tak rzadką w krajach LDC.

Ponadto rozwój demokratycznych Indii nie rozkłada się według stałej, z góry ustalonej sekwencji etapów. Nowoczesne struktury w procesie decyzyjnym w Indiach są dobrze zorganizowane i w znacznym stopniu zinstytucjonalizowane. Mimo to kultura polityczna pozostaje w wielu aspektach zaściankowa, a styl polityki wybitnie tradycjonalistyczny, spersonalizowany, natomiast, co ważne, często oparty na politycznym konsensusie. Wszelkie nierówności i problemy społeczne, w tym ubóstwo, analfabetyzm, korupcja czy biurokracja wynikają do pewnego stopnia z wewnętrznego i międzynarodowego porządku gospodarczego i procesu globalizacji, ale w co najmniej tym samym stopniu są skutkiem indyjskiej różnorodności, także etnicznej.

W najbliższych kilku dziesięcioleciach może być wręcz odwrotnie. To Indie z bogatym doświadczeniem w zakresie polityki rozwoju mogą stać się wyzwaniem dla dotychczasowego ortodoksyjnie liberalnego podejścia w międzynarodowych stosunkach gospodarczych. Procesy zachodzące w Indiach, z racji specyfiki i potencjału tej gospodarki, z oczywistych względów nie poddają się zbyt prostym klasyfikacjom liberalnych rynków światowych.

\section{Prognoza gospodarcza: do 2020}

Rezultatem reform II generacji, idących w parze z korzystnymi przemianami demograficznymi, będzie osiagnięcie średniorocznego wzrostu gospodarczego na poziomie $8-10 \%$ przez najbliższe 13 lat. Ma to pozwolić na przynajmniej trzyipółkrotny wzrost PKB per capita w stosunku do roku prognozy (2002) i mieć bezpośrednie 
przełożenie na poprawę jakości życia Indusów. Walka z ubóstwem ma przynieść wymierne efekty już w 2012 r., kiedy liczba ludności żyjącej poniżej granicy ubóstwa ma wynieść $10 \%$. Celem reform jest nie tylko walka z ubóstwem i stworzenie pokaźnego rynku wewnętrznego, ale i przywrócenie należnej pozycji Indii w handlu światowym. Przeciwnicy liberalizacji gospodarki w Indiach podkreślają, że udział Indii w handlu światowym zmalał z $2 \%$ do $0,9 \% \mathrm{w}$ latach $1947-1987^{28}$, a w latach 90. wzrósł zaledwie z 0,6 do $0,7 \%$, a w 2005 r. wyniósł $0,82 \%{ }^{29}$. Wzrost stymulowany przez reformy, jak przyjęto nazywać postulowany model trwałego zrównoważonego wzrostu w Indiach, poprzez dynamiczny wzrost eksportu o około $15 \%$ rocznie ma zagwarantować wzrost znaczenia Indii w handlu międzynarodowym ${ }^{30}$. Reformom w tym zakresie sprzyjać powinna idea pobudzenia handlu w regionie Azji Południowej. Udział Indii w handlu światowym w 2009 r., zdaniem ministra handlu i przemysłu Kamala Natha, ma wynieść $1,5 \%{ }^{31}$. Regionalna wymiana handlowa pozostaje jednak na bardzo niskim poziomie.

Indie, jako dynamicznie rozwijająca się gospodarka, z każdym rokiem potrzebują coraz więcej surowców energetycznych. Tym samym Indie stają się coraz bardziej zależne od zewnętrznych źródeł energii. W 2002 r. udział surowców energetycznych w całkowitym imporcie wyniósł ok. 20\%. Prognozy wskazują na to, że w ciagu najbliższych kilkunastu lat $90 \%$ indyjskiego zapotrzebowania na ropę naftową pochodzić będzie z importu ${ }^{32}$, głównie z krajów Zatoki Perskiej. Indie staną się przez to aktorem globalnym na rynku energii, pod warunkiem, że uda im się ustalić strategiczne stosunki z państwami Zatoki.

Biorąc pod uwagę całościową siłę państwa, należy wziąć pod uwagę kombinację wszystkich czynników mocarstwowości. Niewątpliwie, biorąc pod uwagę czynnik demograficzny, Indie, które w XXI w. będą najliczniejszym państwem świata pod względem ludności, mogą pretendować do statusu mocarstwa w tym względzie. Ponadto ponadprzeciętny wzrost gospodarczy, nazywany wręcz indyjskim cudem, będzie wspierać te aspiracje. Kluczowe pozostaną jednak inne, jak dotąd nierozwiązane kwestie. Dopiero właściwe wykorzystanie wzrostu gospodarczego, dopasowanie

\footnotetext{
${ }^{28}$ W porównaniu z szybkim wzrostem eksportu usług, produkcji i eksportu IT oraz eksportu wyrobów przemysłowych w Chinach.

${ }_{29}$ India's share in global trade at 0.82proc., ,Economic Times”, 29.04.2005. URL < http://www. accessmylibrary.com/coms2/summary_0286-6509332_ITM>, 16.09.2005.

${ }^{30}$ W 2002 r. indyjski eksport wynosił 51 mld USD. Realny poziom eksportu w 2020 r. ma wynieść wg prognoz ok. 800 mld USD. Źródło: Vijay L. Kelkar, South Asia in 2020 ..., cyt. wyd., s. 95.

${ }_{31}$ India to double its share of global trade: Commerce and Industry Minister Kamal Nath, „India Daily" 7.02.2005, URL < http://www.indiadaily.com/editorial/1538.asp>, 16.09.2007.

${ }^{32}$ Import zaś będzie równy całej obecnej produkcji ropy naftowej w Arabii Saudyjskiej. Vijay L. Kelkar, South Asia in 2020..., cyt. wyd., s. 95.
} 
działań modernizacyjnych armii do rzeczywistych potrzeb bezpieczeństwa, trafne koncepcje rozwoju stosunków regionalnych, kontynuacja reform i zwiększenie roli Indii w świecie poprzez fora wielostronne może rzeczywiście prowadzić do długofalowego zwiększenia potencjału państwa. Nie należy bowiem zapominać o strategicznych wyzwaniach Indii. Elementy sukcesu Indii ostatnich 16 lat łączą się parami z kolejnymi wyzwaniami dla rozwoju i na ich drodze do mocarstwowości: powstanie chłonnego rynku wewnętrznego i klasy średniej z walką z ubóstwem, wysokie tempo wzrostu gospodarczego z nierównomiernym rozwojem stanów, demokratyczny system rządów z biurokracją, korupcją i niestabilnością koalicji rządowych.

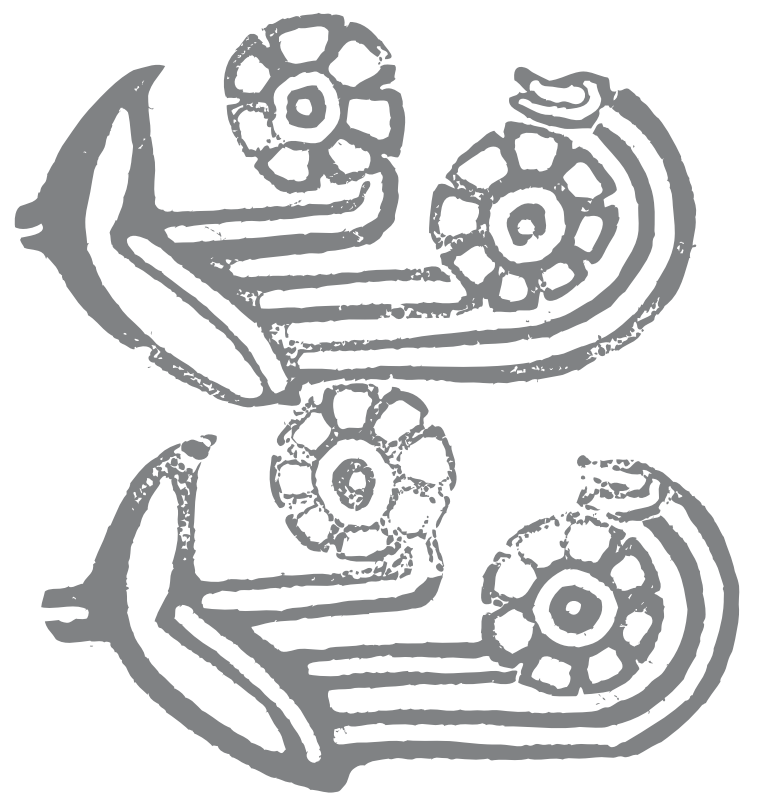

